\title{
Effect of Rhizobium Inoculation Methods on Growth, Nodulation and Yield of Black Gram (Vigna mungo L.)
}

\author{
Shubha Tripathi, Satendra Kumar*, Mukesh Kumar, Ashok Kumar, \\ B. P. Dhyani and Yogesh Kumar \\ ${ }^{1}$ Department of Soil Science and Agricultural Chemistry, ${ }^{2}$ Department of Agronomy, Sardar \\ Vallabbhai Patel University of Agriculture and Technology, Meerut, (UP), India
}

*Corresponding author

\section{A B S T R A C T}

\begin{tabular}{|c|}
\hline Keywords \\
\hline $\begin{array}{l}\text { Black gram, } \\
\text { Rhizobium }\end{array}$ \\
\hline Article Info \\
\hline $\begin{array}{l}\text { Accepted: } \\
12 \text { December } 2020 \\
\text { Available Online: } \\
10 \text { January } 2021\end{array}$ \\
\hline
\end{tabular}

A field experiment was conducted to assess the effect of Rhizobium inoculation on nutrient uptake and productivity at Crop Research Centre of Sardar Vallabhbhai Patel University of Agriculture and Technology, Meerut (U.P.), during kharif season of 2019.The experiment was arranged in randomized block design with nine treatments in three replications. Treatment consisted of $\mathrm{T}_{1}$ (control), $\mathrm{T}_{2}(\mathrm{RDF}), \mathrm{T}_{3}(\mathrm{RDF}+\mathrm{FYM}), \mathrm{T}_{4}$ (RDF + Vermicompost), $\mathrm{T}_{5}$ (RDF + Rhizobium seed inoculation), $\mathrm{T}_{6}(\mathrm{RDF}+$ Rhizobium soil treatment), $\mathrm{T}_{7}\left(\mathrm{RDF}+\right.$ Rhizobium inoculation with Vermicompost), $\mathrm{T}_{8}(\mathrm{RDF}+$ Rhizobium seed inoculation + Rhizobium soil inoculation), $\mathrm{T}_{9}(\mathrm{RDF}+$ Rhizobium seed inoculation + Rhizobium inoculation with Vermicompost. From the data, it was observed that RDF + Rhizobium seed inoculation + Rhizobium inoculation with vermicompost treatment exhibited significant influence on the growth, nodulation, yield attributes and yields, of black gram as compared to control during the year of experimentation with higher values for all the above mentioned parameters and also 90.82 and $41.68 \%$ increase in grains and straw yield.

\section{Introduction}

After cereals and oilseeds, pulses occupy an important place in Indian agriculture. The total world acreage under pulses is about 85.40 Mha with production of $87.40 \mathrm{Mt}$ at productivity $1023 \mathrm{~kg} \mathrm{ha}^{-1}$ production with 34 and $26 \%$ respectively with average productivity of $835 \mathrm{~kg} \mathrm{ha}^{-1}$ (Agricultural Statistics Division, Directorate of Economics and Statistics, 2019). $70 \%$ of the total world's black gram and green gram production comes from India, of which black gram constitutes $1.65 \mathrm{Mt}$ with the share of $12.4 \%$ (Elzebroek and Wind, 2008). Pulses are excellent source of high quality protein, essential amino acids, fatty acids, fibers, minerals and vitamins. The protein level of black gram is quite high i.e about $24 \%$ with nutritional value of $10.9 \%$ moisture, $1.4 \%$ fats, $60.3 \%$ carbohydrates and $3.4 \%$ ash (Shroti et al., 2018). It improves soil health by enriching nitrogen status and also maintains sustainability of the cropping systems. Most 
of its nitrogen requirement is fulfilled by symbiotic nitrogen fixation from air and substantial amount of residual nitrogen and organic matter are left behind for subsequent crops. These crops do not have much nutritional requirements and these requirements can be fulfilled using various organic manures and bio-fertilizers which prove to be as cheapest and environmentally sound practice of applying nutrition to soil and plant.

Vermicompost have been effective in promoting the development of beneficial organisms in the soil. It enhances the growth, yield and quality of crops (Meena 2013; Mujahid and Gupta, 2010) and also increases bio-fertilizers efficiency. FYM through its positive effects on soil physical, chemical and biological properties and balanced plant nutrition plays an important role in improving the fertility and productivity of soils (Kumar et al., 2011). Although, it cannot be considered as a major source of nutrients but can be regarded as a good complimentary and supplementary source with mineral or chemical fertilizers. Use of organic source of nutrient is majorly appreciated over any chemical fertilizer due to the fact that they are not involved in causing any type of pollution and they cut those higher costs of cultivation that are caused by using mineral fertilizers.

Black gram, being leguminous crop, use symbiotic nitrogen fixation which is performed with the help of bacterium called Rhizobia as an important source to fulfil its major part of nitrogen requirement (Pareek, 1978).This symbiotic nitrogen fixation proves to an important source of nitrogen, and around 200 to $300 \mathrm{~kg}$ nitrogen $\mathrm{ha}^{-1}$ is often fixed by various legume crops and pasture species (Dudeja and Duhan, 2005). These microbes vary in number, effectiveness and nodulation. Although Rhizobia is great source of symbiotic nitrogen fixation but sometimes due to less number of Rhizobia and ineffective native Rhizobia, nodulation and nitrogen fixation does not occur properly. To ensure efficient population of effective Rhizobia in soil, these are introduced in soil from outside in the form of biofertilizers. Seed treatment as well as soil application is the way to apply biofertilizer. Another approach may be application of biofertilizer through organic sources.

\section{Materials and Methods}

The field experiment was conducted in kharif season of 2019 at Crop Research Centre, Sardar Vallabhbhai Patel University of Agriculture and Technology, Meerut (U.P.), India, to evaluate the "Effect of Rhizobium inoculation methods on root nodulation, nutrient uptake and productivity of Black gram (Vigna mungo L. Hepper)". The experiment was arranged in randomized block design with nine treatments in three replications, each plot size being $3.0 \mathrm{~m} \mathrm{x}$ $4.0 \mathrm{~m}$. Treatment consisted of $\mathrm{T}_{1}$ (control), $\mathrm{T}_{2}$ $(\mathrm{RDF}), \mathrm{T}_{3}(\mathrm{RDF}+\mathrm{FYM}), \mathrm{T}_{4}(\mathrm{RDF}+$ Vermicompost), $\mathrm{T}_{5}$ (RDF + Rhizobium seed inoculation), $\mathrm{T}_{6}$ (RDF + Rhizobium soil treatment), $\mathrm{T}_{7}(\mathrm{RDF}+$ Rhizobium inoculation with Vermicompost), $\mathrm{T}_{8}$ (RDF + Rhizobium seed inoculation + Rhizobium soil inoculation), $\mathrm{T}_{9}$ (RDF + Rhizobium seed inoculation + Rhizobium inoculation with Vermicompost). Soil collected from research farm was analysed by standard procedure for various initial physicochemical properties given in parentheses, viz. bulk density $(1.38 \mathrm{~g}$ $\left.\mathrm{cm}^{-3}\right)$, particle density $\left(2.65 \mathrm{~g} \mathrm{~cm}^{-3}\right), \mathrm{pH}(8.2)$, EC $\left(0.28 \mathrm{dSm}^{-1}\right)$, organic carbon $(0.45 \%)$, porosity $(46.52 \%)$, available $\mathrm{N}\left(150.0 \mathrm{~kg} \mathrm{ha}^{-}\right.$ $\left.{ }^{1}\right)$, available $\mathrm{P}\left(11.30 \mathrm{~kg} \mathrm{ha}^{-1}\right)$ and available $\mathrm{K}$ $\left(170.0 \mathrm{~kg} \mathrm{ha}^{-1}\right)$.For preparing an experimental field 1 deep ploughing and 2 harrowing was done and pre sowing irrigation was given at least 10 days before sowing. 
Recommended dose of NPK (20:60:00) was applied through urea, single superphosphate. Also FYM and Vermicompost were applied in the field @ 20-25 tonnes ha ${ }^{-1}$ and 5 tonnes $\mathrm{ha}^{-1}$ respectively. Urad-10B strain of Rhizobium leguminosarum var. phaseoli brought from IARI, New Delhi was used to treat seed, vermicompost and soil. For $10 \mathrm{~kg}$ seed $200 \mathrm{~g}$ of Rhizobium culture was used to inoculate the seed. For this, 5\% solution of jaggery in water was prepared.

The water was taken in amount which is enough to moisten the seed. In this solution one packet of Rhizobium culture was added and mixed well. The coating of seed with prepared slurry was done. Then the seeds were dried in shade and sown immediately. Similarly, manual mixing of Rhizobium with Vermicompost, FYM or for its incorporation in soil was done. The black gram variety Shekhar-2 was sown at the rate of $15 \mathrm{~kg}$ ha ${ }^{1}$.Intercultural operations viz., weeding, irrigation and insecticide spray were done as and when required. The yield, nutrient content and uptake and physico-chemical properties were recorded at pertinent stages.

\section{Results and Discussion}

\section{Growth parameters}

In the present study Rhizobium inoculation methods exhibited a significant effect on various growth parameters viz. plant height, number of branches and dry matter accumulation plant $^{-1}$ recorded at different time periods of crop growth (Table-1 and Fig. $1.1,1.2,1.3)$. At 30 and 60 DAS and at harvest stage the treatment $\mathrm{T}_{9}$ (RDF + Rhizobium seed inoculation + Rhizobium inoculation with Vermicompost) shows significantly higher plant height (23.6, 54.5, $57.8 \mathrm{~cm}$ ) than the rest of the treatments. The shortest plant height was obtained in control plot at all the time period of crop growth
(18.1, 43.3, $46.0 \mathrm{~cm}$, respectively). Similar results were found for number of branches plant $^{-1}$, number of trifoliate leaf plant ${ }^{-1}$ and dry matter accumulation plant ${ }^{-1}$ with higher values as 3.83, 4.92 and 5.96, 3.9, 9.6, 8.5, and $7.10,14.06,14.50 \mathrm{~g} \mathrm{plant}^{-1}$ respectively at 30,60 and harvest stage.

Significant increase in plant height was found due to Rhizobium inoculation, which may maintain favourable balance between the applied nutrients in the plant for its optimum growth while elongation and chlorophyll biosynthesis in turn, improve the branches plant $^{-1}$. The result is supported by Singh and Pareek (2003), Sripriya et al., (2005), Kumar and Elamathi (2007) Bhuiyan et al., (2008) and Giri et al., (2010).

\section{Nodulation}

The number of nodules plant ${ }^{-1}$ and their dry weight in black gram was significantly influenced by Rhizobium inoculation methods (Table-2 and Fig. 2). The highest number of nodules and their dry weight 41.0 plant $^{-1}$ and $50.10 \mathrm{mg}$ plant $^{-1}$, respectively were recorded in $\mathrm{T}_{9}$ (RDF + Rhizobium seed inoculation + Rhizobium inoculation with Vermicompost) at 45 DAS. However, lowest number of nodules and their dry weight 24.3 plant $^{-1}$ and 34.18 $\mathrm{mg}$ plant $^{-1}$ respectively were recorded in control $\left(\mathrm{T}_{1}\right)$.

It might have resulted due to more competitive ability of microbes near roots which is the site for microbial infection. Welldeveloped root system provides more evidence for infection resulting in greater number of nodules.

These finding are found relevant to Hussain et al., (2015), Dhakal et al., (2016), Meena and Ram (2016), Kant et al., (2016) and Mohammad et al., (2017). 
Table.1 Effect of Rhizobium inoculation methods on growth parameters of black gram

\begin{tabular}{|c|c|c|c|c|c|c|c|c|c|c|c|c|}
\hline \multirow[t]{2}{*}{ Treatments } & \multicolumn{3}{|c|}{ Plant height(cm) } & \multicolumn{3}{|c|}{ No. of branch plant ${ }^{-1}$} & \multicolumn{3}{|c|}{ No. of trifoliate leaf plant } & \multicolumn{3}{|c|}{$\begin{array}{c}\text { Dry matter accumulation } \\
\left(\text { g plant }^{-1}\right)\end{array}$} \\
\hline & $\begin{array}{c}30 \\
\text { DAS }\end{array}$ & $\begin{array}{c}\text { 60 } \\
\text { DAS }\end{array}$ & $\begin{array}{c}\text { At } \\
\text { harvest }\end{array}$ & $\begin{array}{c}30 \\
\text { DAS }\end{array}$ & $\begin{array}{c}\text { 60 } \\
\text { DAS }\end{array}$ & $\begin{array}{c}\text { At } \\
\text { harvest }\end{array}$ & $\begin{array}{c}30 \\
\text { DAS }\end{array}$ & $\begin{array}{c}\text { 60 } \\
\text { DAS }\end{array}$ & $\begin{array}{c}\text { At } \\
\text { harvest }\end{array}$ & $\begin{array}{c}30 \\
\text { DAS }\end{array}$ & $\begin{array}{c}\text { 60 } \\
\text { DAS }\end{array}$ & $\begin{array}{c}\text { At } \\
\text { harvest }\end{array}$ \\
\hline $\mathbf{T}_{1}-$ Control & 18.1 & 43.3 & 46.0 & 2.14 & 3.25 & 4.41 & 1.9 & 6.3 & 5.2 & 5.54 & 8.78 & 9.50 \\
\hline $\mathbf{T}_{2}-\mathbf{R D F}$ & 20.0 & 46.3 & 51.2 & 2.42 & 3.64 & 4.78 & 2.1 & 7.7 & 6.6 & 5.82 & 9.90 & 11.20 \\
\hline$T_{3}-\mathrm{RDF}+\mathrm{FYM}$ & 20.1 & 47.5 & 51.9 & 2.66 & 3.79 & 5.19 & 2.3 & 7.9 & 6.8 & 5.96 & 10.20 & 12.55 \\
\hline $\begin{array}{l}\mathrm{T}_{4}-\quad \mathrm{RDF} \\
\text { Vermicompost }\end{array}$ & 21.1 & 49.6 & 53.0 & 2.82 & 3.90 & 5.26 & 2.7 & 8.5 & 7.2 & 6.34 & 11.26 & 12.30 \\
\hline $\begin{array}{l}\mathrm{T}_{5}-\mathrm{RDF}+\text { Rhizobium } \\
\text { seed inoculation }\end{array}$ & 21.9 & 52.1 & 55.7 & 3.28 & 4.57 & 5.69 & 3.4 & 9.3 & 8.2 & 6.70 & 12.84 & 13.65 \\
\hline $\begin{array}{l}\mathrm{T}_{6}-\mathrm{RDF}+\text { Rhizobium } \\
\text { soil treatment }\end{array}$ & 21.4 & 49.8 & 53.9 & 2.98 & 4.21 & 5.45 & 2.8 & 8.7 & 7.4 & 6.51 & 11.68 & 12.90 \\
\hline $\begin{array}{l}\mathrm{T}_{7}-\mathrm{RDF}+\text { Rhizobium } \\
\text { inoculation with } \\
\text { Vermicompost }\end{array}$ & 21.6 & 51.0 & 54.7 & 3.10 & 4.36 & 5.57 & 3.2 & 9.1 & 7.9 & 6.53 & 12.15 & 13.50 \\
\hline $\begin{array}{l}\mathrm{T}_{8}-\mathrm{RDF}+\text { Rhizobium } \\
\text { seed inoculation }+ \\
\text { Rhizobium } \\
\text { inoculation }\end{array}$ & 22.5 & 53.3 & 56.3 & 3.58 & 4.78 & 5.82 & 3.6 & 9.4 & 8.3 & 6.88 & 13.58 & 13.68 \\
\hline $\begin{array}{l}\mathrm{T}_{9}-\mathrm{RDF}+\text { Rhizobium } \\
\text { seed inoculation }+ \\
\text { Rhizobium inoculation } \\
\text { with Vermicompost }\end{array}$ & 23.6 & 54.5 & 57.8 & 3.83 & 4.92 & 5.96 & 3.9 & 9.6 & 8.5 & 7.10 & 14.06 & 14.50 \\
\hline$S E m \pm$ & 0.7 & 1.5 & 1.8 & 0.14 & 0.18 & 0.26 & 0.10 & 0.30 & 0.30 & 0.17 & 0.38 & 0.49 \\
\hline$C D(P=0.05)$ & 1.9 & 4.3 & 5.2 & 0.39 & 0.52 & 0.75 & 0.30 & 0.90 & 0.88 & 0.48 & 1.10 & 1.44 \\
\hline
\end{tabular}


Table.2 Effect of Rhizobium inoculation methods on nodulation of black gram

\begin{tabular}{|c|c|c|c|c|}
\hline \multirow[t]{2}{*}{ Treatment } & \multicolumn{2}{|c|}{ Number of root nodules plant ${ }^{-1}$} & \multicolumn{2}{|c|}{ Dry weight of nodules plant ${ }^{-1}\left(\mathrm{mg} \mathrm{plant}^{-1}\right)$} \\
\hline & 45 DAS & 60 DAS & 45 DAS & 60 DAS \\
\hline $\mathbf{T}_{1}-$ Control & 24.3 & 22.2 & 34.18 & 28.22 \\
\hline $\mathbf{T}_{2}-\mathbf{R D F}$ & 30.8 & 26.0 & 42.36 & 33.71 \\
\hline $\mathrm{T}_{3}-\mathrm{RDF}+\mathrm{FYM}$ & 32.1 & 29.7 & 43.38 & 35.16 \\
\hline$T_{4}-$ RDF + Vermicompost & 34.0 & 31.1 & 45.12 & 37.62 \\
\hline $\mathrm{T}_{5}-\mathrm{RDF}+$ Rhizobium seed inoculation & 38.6 & 35.4 & 47.56 & 39.41 \\
\hline $\mathrm{T}_{6}-\mathrm{RDF}+$ Rhizobium soil treatment & 36.2 & 32.0 & 45.41 & 37.72 \\
\hline $\begin{array}{l}\mathrm{T}_{7}-\mathrm{RDF}+\text { Rhizobium inoculation with } \\
\text { Vermicompost }\end{array}$ & 37.3 & 33.3 & 46.34 & 38.28 \\
\hline $\begin{array}{l}\text { T }_{8}-\text { RDF + Rhizobium seed inoculation + } \\
\text { Rhizobium soil inoculation }\end{array}$ & 39.2 & 36.2 & 48.58 & 40.38 \\
\hline $\begin{array}{l}\text { T}_{9}-\text { RDF + Rhizobium seed inoculation }+ \\
\text { Rhizobium inoculation with Vermicompost }\end{array}$ & 41.0 & 38.6 & 50.10 & 42.67 \\
\hline$S E m \pm$ & 0.48 & 0.43 & 0.64 & 0.58 \\
\hline$C D(P=0.05)$ & 1.42 & 1.30 & 1.89 & 1.72 \\
\hline
\end{tabular}

Table.3 Effect of Rhizobium inoculation methods on yield attributes of black gram

\begin{tabular}{|c|c|c|c|c|}
\hline Treatment & Pod length (cm) & No. of pod plant ${ }^{-1}$ & No. of grain pod ${ }^{-1}$ & Test weight (g) \\
\hline $\mathrm{T}_{1}-$ Control & 4.0 & 18.30 & 4.09 & 29.25 \\
\hline $\mathbf{T}_{2}-\mathbf{R D F}$ & 4.6 & 19.10 & 4.60 & 31.26 \\
\hline $\mathrm{T}_{3}-\mathrm{RDF}+\mathrm{FYM}$ & 4.8 & 19.70 & 4.82 & 32.28 \\
\hline $\mathrm{T}_{4}-\mathrm{RDF}+$ Vermicompost & 5.1 & 20.65 & 5.17 & 32.68 \\
\hline $\mathrm{T}_{5}-\mathrm{RDF}+$ Rhizobium seed inoculation & 6.1 & 23.10 & 5.58 & 34.88 \\
\hline $\mathrm{T}_{6}-\mathrm{RDF}+$ Rhizobium soil treatment & 5.5 & 21.72 & 5.32 & 33.21 \\
\hline $\mathbf{T}_{7}-\mathbf{R D F}+$ Rhizobium inoculation with Vermicompost & 5.8 & 22.14 & 5.41 & 33.72 \\
\hline $\begin{array}{l}\mathrm{T}_{8}-\mathrm{RDF}+\text { Rhizobium seed inoculation }+ \text { Rhizobium soil } \\
\text { inoculation }\end{array}$ & 6.5 & 24.63 & 5.74 & 35.02 \\
\hline $\begin{array}{l}\text { T9 }_{9} \text { - RDF + Rhizobium seed inoculation + Rhizobium } \\
\text { inoculation with Vermicompost }\end{array}$ & 6.9 & 25.68 & 5.95 & 35.42 \\
\hline$S E m \pm$ & 0.32 & 0.51 & 0.25 & 0.44 \\
\hline$C D(P=0.05)$ & 0.92 & 1.49 & 0.72 & NS \\
\hline
\end{tabular}


Table.4 Effect of Rhizobium inoculation methods on grain, straw, biological yield (q ha $\left.{ }^{-1}\right)$ and harvest index (\%) of black gram

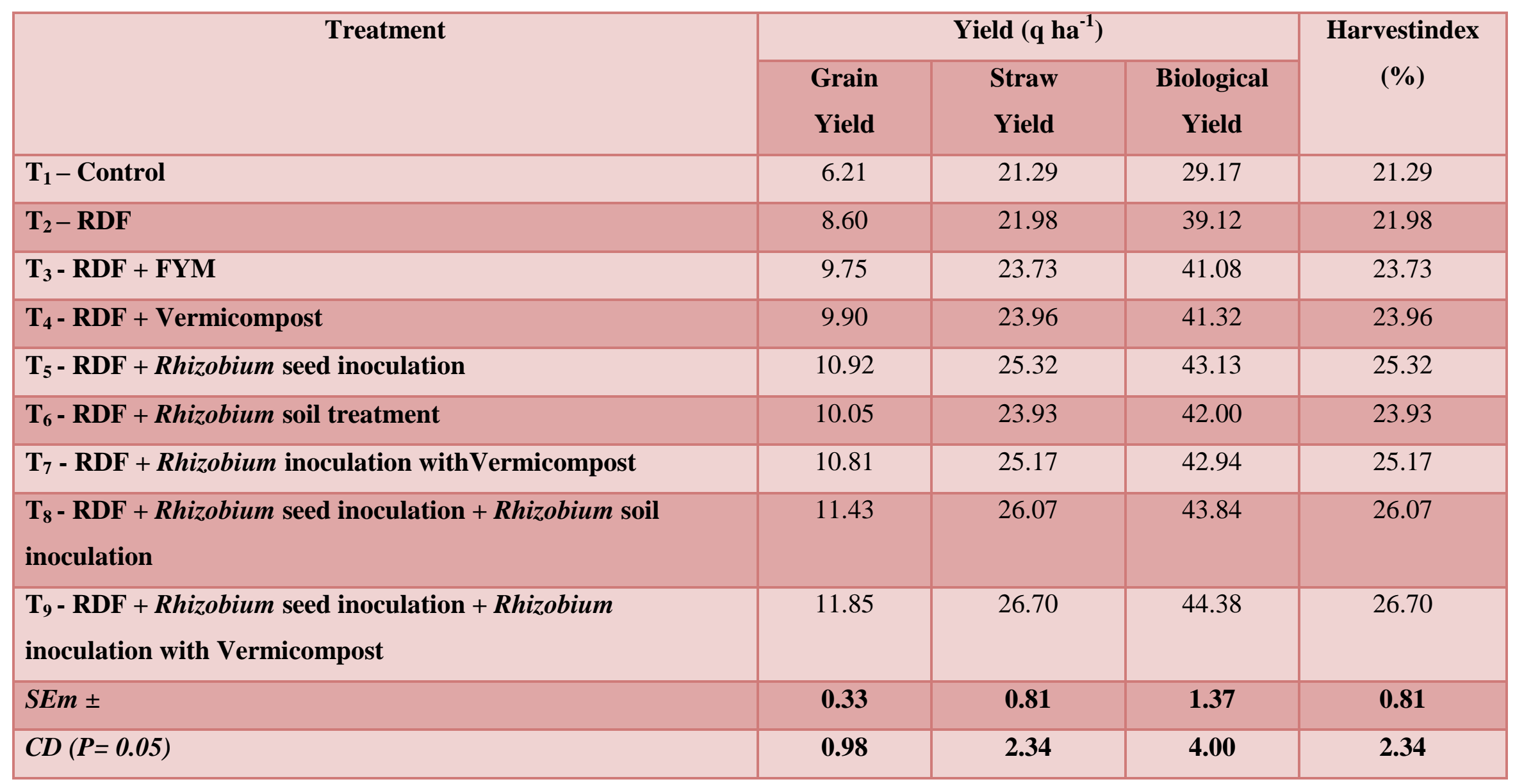


Fig.1.1 Effect of Rhizobium inoculation methods on plant height $(\mathrm{cm})$ of black gram plant ${ }^{-1}$ black gram at different growth periods

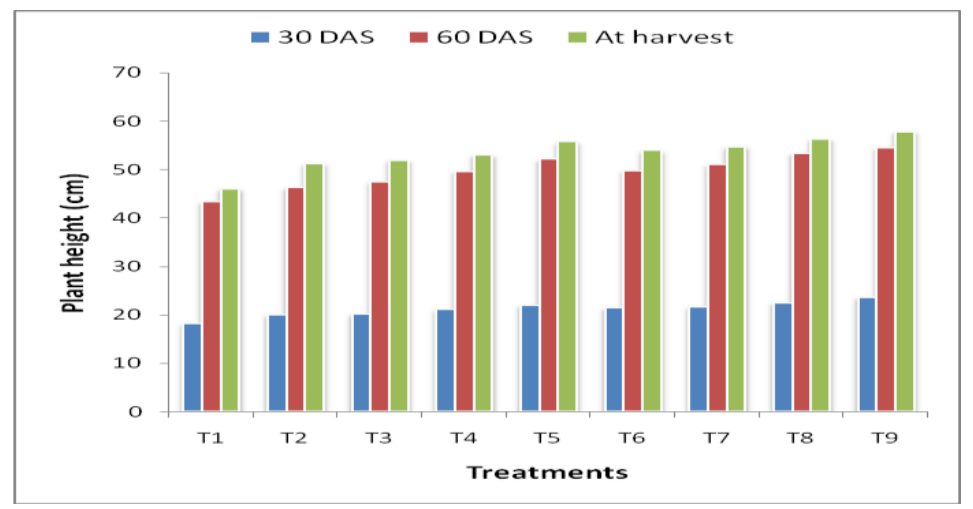

Fig.1.2 Effect of Rhizobium inoculation methods on number of branches plant ${ }^{-1}$ at different growth periods

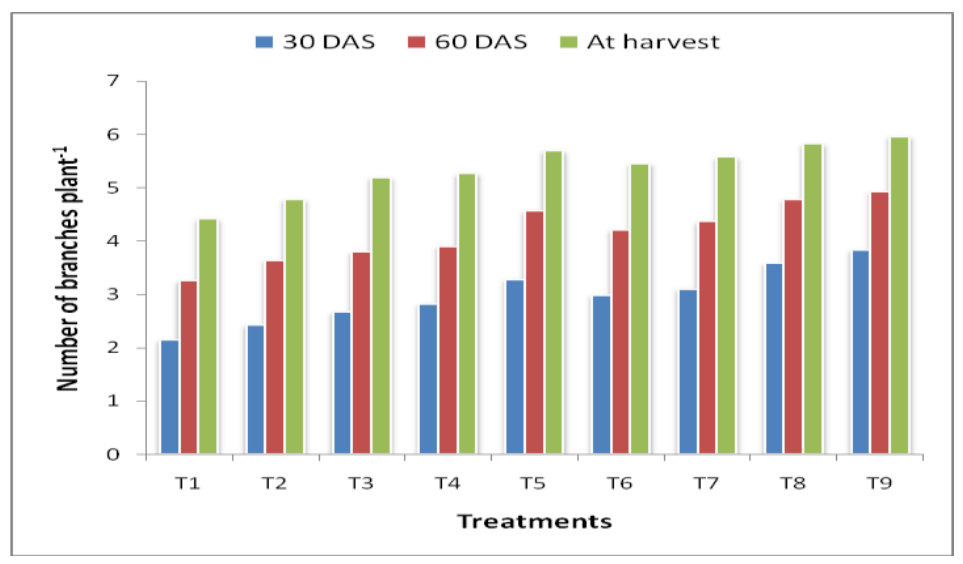

Fig.1.3 Effect of Rhizobium inoculation methods on number of trifoliate leaf plant ${ }^{-1}$ (left) and dry matter accumulation (g plant ${ }^{-1}$ ) (right) of black gram at different growth periods
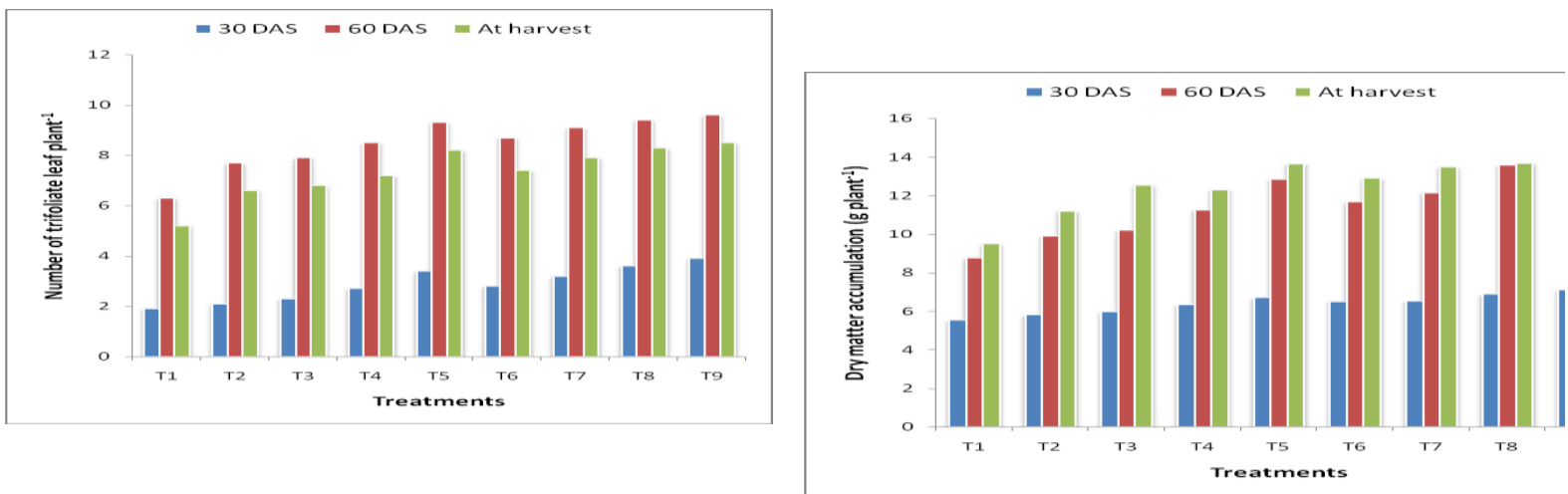
Fig.2 Effect of Rhizobium inoculation methods on number of nodules plant ${ }^{-1}$ and dry weight of nodules plant ${ }^{-1}\left(\mathrm{mg} \mathrm{plant}^{-1}\right)$ at different growth periods of black gram
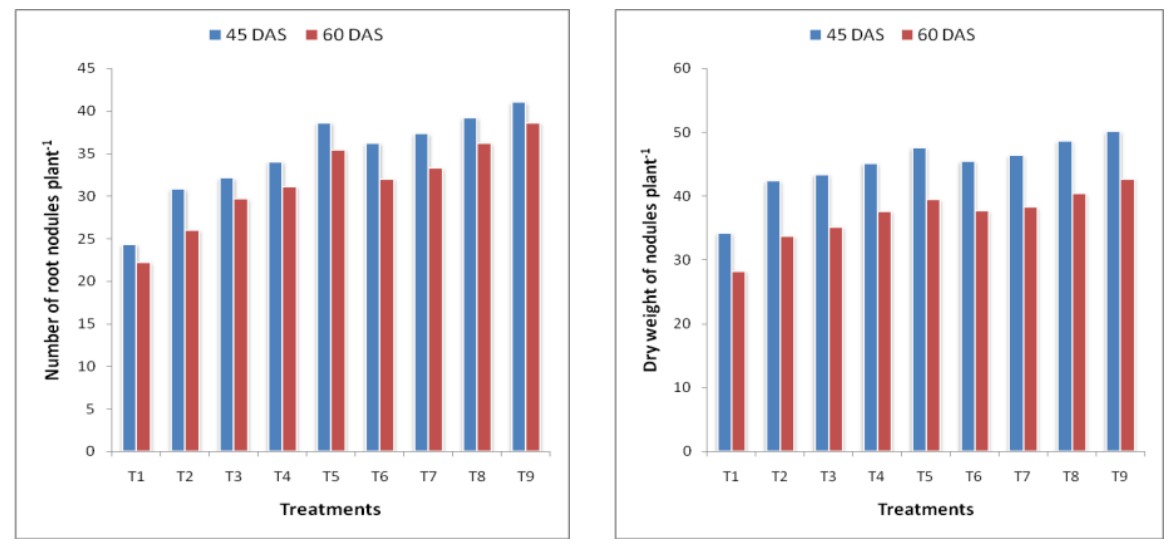

Fig.3 Effect of Rhizobium inoculation methods on yield attributes of black gram

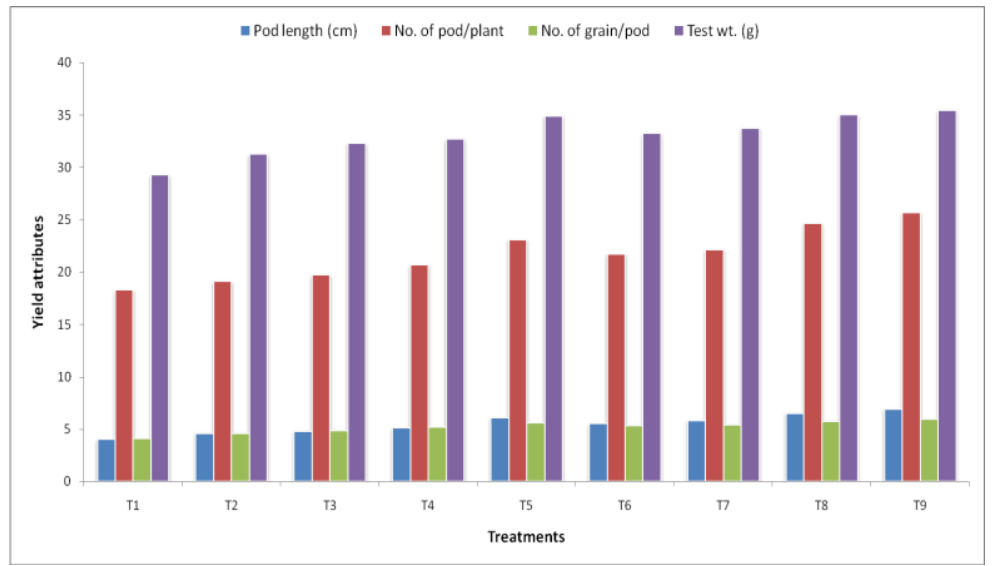

Fig.4 Effect of Rhizobium inoculation methods on grain, straw, biological yield (q ha ${ }^{-1}$ ) and harvest index $(\%)$ of black gram

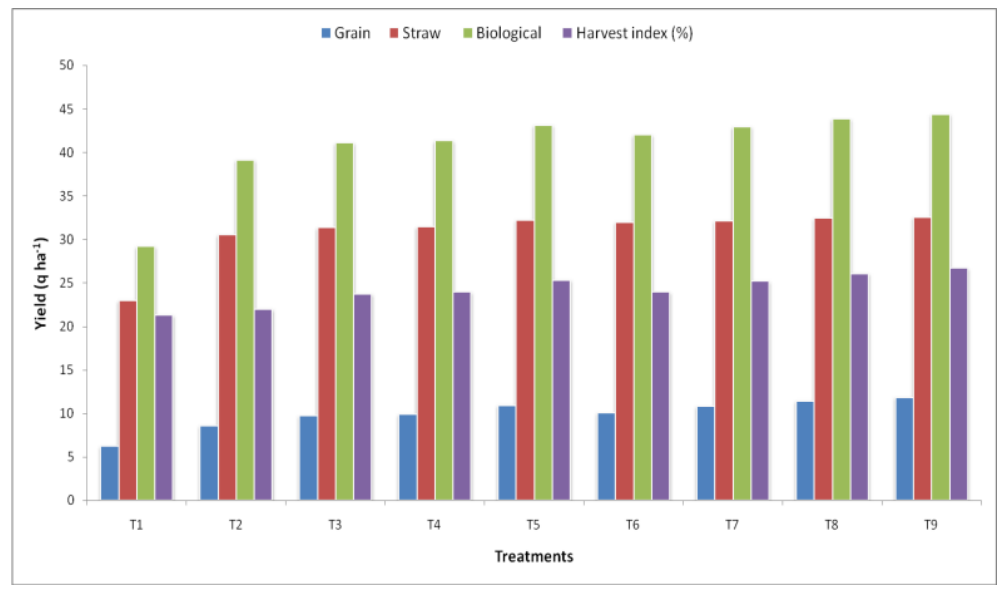




\section{Yield and Yield Attributes}

\section{Yield attributes}

Yield attributes viz. pod length $(\mathrm{cm})$, number of pods plant ${ }^{-1}$, number of grains pod $^{-1}$ and test weight (Table-3 and Fig. 3) differs significantly under the treatment $\mathrm{T}_{9}(\mathrm{RDF}+$ Rhizobium seed inoculation + Rhizobium inoculation with Vermicompost) and sole application of Rhizobium inoculation. The highest pod length $(\mathrm{cm})$, number of pods plant ${ }^{-1}$, number of grains pod $^{-1}$ and test weight (g) $(6.9,25.68,5.95$ and 35.42 , respectively) were found in $\mathrm{T}_{9}(\mathrm{RDF}+$ Rhizobium seed inoculation + Rhizobium inoculation with Vermicompost) while, lowest in control $\left(\mathrm{T}_{1}\right)$. In the process of tissue differentiation from somatic to reproductive, meristmatic activity and development of floral primordial might have increased with Rhizobium inoculation methods resulting in more flowers and pods and ultimately the higher grain yield. The result is supported by Singh and Pareek (2003), Sripriya et al., (2005), Kumar and Elamathi (2007) and Ghosh and Joseph (2008).

\section{Yield}

The maximum grain yield of $11.85 \mathrm{q} \mathrm{ha}^{-1}$ (Table-4 and Fig. 4), statistically at par with $\mathrm{T}_{8}$ (RDF + Rhizobium seed inoculation + Rhizobium soil treatment) and significantly higher than remaining treatments was found in $\mathrm{T}_{9}(\mathrm{RDF}+$ Rhizobium seed inoculation + Rhizobium inoculation with Vermicompost), which were higher over control by 90.82 and $84.05 \%$ in $\mathrm{T}_{8}$ and $\mathrm{T}_{9}$, respectively. Similar result was found for harvest index with values highest in $\mathrm{T}_{9}$ i.e. $26.70 \%$ and lowest in control i.e. $21.29 \%$. The highest straw and biological yield (32.53 and $44.38 \mathrm{q} \mathrm{ha}^{-1}$ ) were found in $\mathrm{T}_{9}$ (RDF + Rhizobium seed inoculation + Rhizobium inoculation with Vermicompost) followed by $32.41 \mathrm{q} \mathrm{ha}^{-1}$ and
$43.84 \mathrm{q} \mathrm{ha}^{-1}$ in $\mathrm{T}_{8}(\mathrm{RDF}+$ Rhizobium seed inoculation + Rhizobium soil treatment) while, lowest 22.96 and $29.17 \mathrm{q} \mathrm{ha}^{-1}$ was found in control $\left(\mathrm{T}_{1}\right)$, respectively. The improvement in yield and yield attributing character might be attributed to the fact that combined and balanced application of Rhizobium inoculation increases photosynthetic activity of leaves, translocation of photosynthates from source to sink with consequent improvement, nutrients uptake and better metabolism and increase efficiency of other nutrients. The results of our study are in line with the findings of Dudeja and Duhan (2005), Sahu and Singh (2009), Kachhave et al., (2009) and Sardar et al., (2016).

From the above study it is concluded that application of Rhizobium treated seed with Rhizobium treated vermicompost and recommended fertilizers was found superior than rest of the treatments in terms of growth, nodulation and yield parameters of black gram. Its application resulted in higher values for all the different aspects studied above. Thus for obtaining higher productivity of black gram and sustainable soil health the Rhizobium treated seed should be sown with Rhizobium treated vermicompost and recommended fertilizers.

\section{References}

Anonymous. (2019) Agricultural Statistics Division, Directorate of Economics and Statistics.

Bhuiyan, M.M.H., Rahman, M.M., Afroze, F., Sutradhar, G.N.C. and Bhuiyan, M.S.I. (2008) Effect of phosphorus, molybdenum and Rhizobium inoculation on growth and nodulation of mungbean. J. Soil. Nature 2(2): 2530.

Dhakal, Y., Meena, R.S. and Kumar, S. (2016) Effect of INM on nodulation, 
yield, quality and available nutrient status in soil after harvest of greengram. Legume Research-An International Journal 39(4): 590-594.

Dudeja, S.S. and Duhan, J.S. (2005) Biological nitrogen fixation research in pulses with special reference to mungbean and urdbean. Indian Journal of Pulses Research 18(2):107.

Elzebroek, T. and Wind, K. (2008) Guide to Cultivated Plants.CAB International, United Kingdom. 262.

Ghosh, M.K. and Joseph, S.A. (2008) Influence of biofertilizers, foliar application of DAP and sulphur sources on yield and yield attributes of summer green gram (Vignaradiata L. Wilczek). Legume Research-An International Journal, 31(3): 232-233.

Giri, N. and Joshi, N.C. (2010) Growth and yield response of chick pea (Cicer arietinum) to seed inoculation with Rhizobium sp. Nature and science 8(9): 232-236.

Hussain, N., Mehdi, M., Dar, S.N.R., Hussain, M. and Fatima, N. (2015) Effect of Rhizobium and PSB on growth and yield attributes of blackgram (Vigna mungo L.).Ecology, Environment and Conservation21(3): 1231-1233.

Kachhave, K.G., Dhage, S.J. and Adsul, R.B. (2009) Associative effect of Rhizobium, PSB and fertilizers on nodulation and yield of blackgram (Vigna mungo) in vertisol. Journal of Maharashtra Agricultural Universities 34(2): 186188.

Kant, Surya, Kumar, Achin., Kumar, Satendra., Kumar, Vipin., Pal, Yogesh. and K. Shukla, A. K. (2016) Effect of Rhizobium, PSB and p-levels on growth, yield attributes and yield of Urdbean (Vigna mungo L.). Journal of Pure and Applied Microbiology 10(4): 3093-3098.
Kumar, A., and Elamathi, S. (2007) Effect of nitrogen levels and rhizobium application methods on yield attributes, yield and economics of black gram (Vigna mungo L.). Intl. J. Agric. Sci. 3(1): 179-180.

Kumar, A.B.M., Gowda, N.C.N., Shetty, G.R. and Karthik, M.N. (2011) Effect of organic manures and inorganic fertilizers on available NPK, microbial density of the soil and nutrient uptake of brinjal. Res. J. Agri. Sci. 2(2): 30407.

Meena, B.S. and Ram, B. (2016) Effect of integrated nutrient management on productivity, soil fertility and economics of blackgram (Vigna mungo) varieties under rainfed condition. Legume Research: An International Journal 39(2).

Meena, R.S. (2013) Response to different nutrient sources on green gram (Vigna radiata L.) productivity. Indian J. Ecol. 40:353-355.

Mohammad, I., Yadav, B.L. and Ahmad, A. (2017) Effect of phosphorus and bioorganics on yield and soil fertility status of Mungbean (Vigna radiata L. Wilczek) under semiarid condition of Rajasthan, India. International Journal of Current Microbiology and Applied Sciences 6(3): 1545-1553.

Mujahid, A.M. and Gupta, A.J. (2010) Effect of plant spacing, organic manures and inorganic fertilizers and their combinations on growth, yield and quality of lettuce (Lactuca sativa).Indian J. Agrl. Sc. 80: 177-81.

Panse, VG. And Sukhatme P.V. (1978) Statistical methods for agricultural workers. ICAR, New Delhi.

Pareek, S.K., Saroha, M.S. and Singh, H.G. (1978) Effect of Sulphur on chlorosis and yield of black gram on calcareous soils. Indian J. Agron. 23(3): 102-107.

Sahu, S. and Singh, P.K. (2009) Effect of 
micronutrients and biofertilizer inoculation on grain yield, protein content, micronutrients content and economics of chickpea. Annals of Agricultural Research 30(1 and2).

Sardar, S., Kumar, Y., Shahi, U.P., Kumar, A., Dhyani, B.P., Yadav, A.K.and Singh, S.P. (2016) Effect of integrated use of bio-fertilizers and vermicompost on nutrient availability, uptake and performance of urd bean (Vigna mungo L.) in sandy loam soil. Plant archives 16(1): 18-22.

Shroti, S.K., Pathak, A., Tiwari, A., Gupta, A. and Chauhan, S.K. (2018) Morphological, physiological and yield analysis of black gram under different levels of FYM, PSB and phosphorus. International Journal of Chemical Studies 6(3): 403-411.

Singh, B. and Pareek, R. G. (2003) Effect of phosphorus and biofertilizers on growth and yield of mungbean (No. RESEARCH).

Sripriya, B., Deotale, R.D., Hatmode, C.N., Titare, P.S., and Thorat, A.W. (2005) Effect of biofertilizers (pressmud, Rhizobium and PSB) and nutrients (NPK) on morpho-physiological parameters of green gram. Journal of Soils and Crops, 15(2), 442-447.

\section{How to cite this article:}

Shubha Tripathi, Satendra Kumar, Mukesh Kumar, Ashok Kumar, B. P. Dhyani and Yogesh Kumar. 2021. Effect of Rhizobium Inoculation Methods on Growth, Nodulation and Yield of Black Gram (Vigna mungo L.). Int.J.Curr.Microbiol.App.Sci. 10(01): 1588-1598. doi: https://doi.org/10.20546/ijcmas.2021.1001.185 